\title{
Manajemen Pembiayaan Pendidikan untuk Meningkatkan Mutu Pendidikan
}

\author{
Hanna Fadhila \\ Universitas Negeri Yogyakarta \\ e-mail: h4nn4fdhl@gmail.com
}

\begin{abstract}
Abstrak: Manajemen pembiayaan pendidikan memegang peranan penting dalam meraih tujuan pendidikan dan meningkatkan mutu pendidikan. Salah satu cara untuk meningkatkan mutu pendidikan adalah dengan memperhatikan standar nasional pendidikan yang berlaku di Indonesia diantaranya adalah standar pembiayaan. Keuangan sekolah yang tersedia perlu dikelola dengan menggunakan fungsi manajemen sehinga manajemen pembiayaan dapat terlaksana secara efektif dan efisien. Fungsi-fungsi dalam manajemen pembiayaan meliputi perencanaan, pembukuan, penggunaan keuangan atau pembelanjaan, pencatatan, pengawasan, serta pertanggungjawaban. Manajemen pembiayaan pendidikan adalah salah satu kunci keberhasilan penyelenggaraan kegiatan belajar mengajar di sekolah karena biaya pendidikan memiliki korelasi yang linier dengan mutu pendidikan.
\end{abstract}

Kata kunci: biaya pendidikan, manajemen keuangan, mutu pendidikan

\section{Education Financing Management to Improve the Quality of Education}

Abstract: Education financing management is playing an important role in achieving educational goals and improving the quality of education. One of the ways to improve the quality of education is considering the national education standard that apply in Indonesia, one of them is financial standard. School-owned finances need to be managed with using the function of management, so the education financing management can be done effectively and efficiently. The functions of financial management are planning, bookkeeping, expenditure, recording, controlling, and accountability. Education financing management is one of the keys to success to do teaching and learning activities in the school because educational budget has a linear correlation with the quality of education.

Keywords: educational budget, financial management, the quality of education

\section{Pendahuluan}

Undang-undang Republik Indonesia

Nomor 20 tahun 2003 tentang Sistem

Pendidikan Nasional Bab I Pasal 1

menyatakan bahwa pendidikan adalah

usaha sadar dan terencana untuk mewujudkan suasana belajar dan proses pembelajaran agar peserta didik secara aktif mengembangkan potensi dirinya untuk memiliki kekuatan spiritual keagamaan, pengendalian diri, kepribadian, kecerdasan, akhlak mulia, serta keterampilan yang diperlukan dirinya, masyarakat, bangsa dan negara (Depdiknas, 2003:4). Mencermati 
isi Undang-undang tersebut, maka pendidikan dapat dikatakan sebagai suatu unsur yang sangat penting dalam kehidupan karena pendidikan dapat menghasilkan output atau lulusan yang berkualitas, sehingga diharapkan lulusan sebagai sumber daya manusia (SDM) dapat memberikan kontribusi dalam pembangunan bangsa.

Kesadaran tentang pentingnya pendidikan yang dapat memberikan harapan dan kemungkinan yang lebih baik di masa mendatang, telah mendorong berbagai upaya dan perhatian seluruh lapisan masyarakat terhadap setiap gerak langkah dan perkembangan dunia pendidikan. Pendidikan sebagai salah satu upaya dalam rangka meningkatkan kualitas hidup manusia, pada intinya bertujuan untuk memanusiakan manusia, mendewasakan, serta merubah perilaku, serta meningkatkan mutu menjadi lebih baik (Fattah, 2004:1).

Pendidikan di Indonesia sendiri merupakan tanggung jawab bersama antara pemerintah, sekolah, dan masyarakat. Dalam meraih pendidikan yang berkualitas, pendidikan memiliki 8 standar yang digunakan sebagai acuan untuk mencapai kualitas pendidikan yang diharapkan. Pemenuhan 8 standar berdasarkan Peraturan Pemerintah Republik Indonesia Nomor 19 tahun 2005 tentang Standar
Nasional Pendidikan meliputi: standar isi, standar kompetensi lulusan, standar proses, standar pendidik dan tenaga kependidikan, standar sarana prasarana, standar penilaian, standar pembiayaan, serta standar pengelolaan. Dapat diketahui bahwa salah satu standar untuk meningkatkan mutu pendidikan di Indonesia adalah standar pembiayaan. Kemampuan pembiayaan merupakan salah satu faktor kunci keberhasilan praktik-praktik penyelenggaraan di sekolah, sehingga pembiayaan memiliki hubungan yang linier dengan mutu pendidikan (Danim, 2005:142).

Pembiayaan pendidikan berperan penting dalam dunia pendidikan, sehingga dapat dikatakan tanpa biaya, proses belajar mengajar di sekolah tidak akan berjalan. Oleh karena itu, pembiayaan pendidikan perlu dikelola dengan efektif dan efisien agar membantu pencapaian tujuan pendidikan. Dalam pelaksanaan pendidikan, pembiayaan adalah potensi yang sangat menentukan keberhasilan suatu layanan pendidikan dan merupakan bagian yang tidak terpisahkan dari manajemen pendidikan. Peran penting pembiayaan dalam proses pembelajaran akan selalu berkaitan erat dengan manajemen sebagai tata kelola dalam mengatur pembiayaan pendidikan di sekolah. Manajemen sebagai suatu proses pengelolaan, pengaturan, dan 
pengurusan dapat diwujudkan dengan melaksanakan fungsi-fungsi manajemen berupa perencanaan, pengorganisasian, penggerakan, dan pengawasan.

\section{Metode Penelitian}

Dalam artikel ini, penulis menggunakan metode penelitian pustaka (library research), yaitu penelitian yang objek kajiannya menggunakan data pustaka berupa buku-buku sebagai sumber data. Penelitian ini dilakukan dengan membaca, menelaah, dan menganalisis beberapa literatur yaitu buku, artikel, dan skripsi.

\section{Manajemen}

Koontz dan Weihrich (dalam Danim, 2005:32) mengemukakan definisi manajemen sebagai "The process of designing and maintaining an environment in which individuals, working together in groups, efficiently accomplish selected aims", yang artinya proses merancang dan memelihara lingkungan di mana individu, bekerja sama dalam kelompok, secara efisien mencapai tujuan yang dipilih.

George R. Terry (dalam Lahaji dan Yusuf, 2020:3) menyatakan "Management is a distinct process consisting of planning, organizing, actuating, and controlling performed to determined and accomplish stated objectives by the use of human being and other resource", artinya manajemen adalah suatu proses yang khas yang terdiri dari tindakan-tindakan perencanaan, pengorganisasian, penggerakan, dan pengawasan yang dilakukan untuk menentukan serta mencapai sasaransasaran yang telah ditentukan melalui pemanfaatan sumber daya manusia dan sumber-sumber lainnya.

$$
\text { Sedangkan Hasibuan }
$$
berpendapat bahwa manajemen adalah ilmu dan seni mengatur proses pemanfaatan sumber daya manusia dan sumber-sumber lainnya secara efektif dan efisien untuk mencapai suatu tujuan tertentu.

Berdasarkan beberapa pendapat di atas, maka dapat disimpulkan bahwa manajemen adalah ilmu dan seni mengatur proses segala sumber untuk mencapai suatu tujuan yang telah disepakati secara efektif dan efisien. Ada beberapa unsur di dalam manajemen, yaitu terkandung tujuan tertentu yang akan dicapai, melibatkan sumber daya manusia dan sumber lainnya, dilakukan melalui beberapa tahapan yang terkoordinasi secara sistematis, serta proses dalam mencapai tujuan dilakukan secara efektif dan efisien.

\section{Fungsi-Fungsi Manajemen}

Tahapan yang dilalui dalam manajemen adalah dengan melaksanakan fungsi-fungsi manajemen. Fungsi manajemen yang populer digunakan di 
Indonesia yaitu planning (perencanaan), organizing (pengorganisasian), actuating (penggerakan), dan controlling (pengawasan). Fungsi-fungsi dasar manajemen tersebut diklasifikasikan oleh George R. Terry.

George R. Terry (dalam Sukarna, 2011:10) menyatakan bahwa "Planning is the selecting and relating of facts and the making and using of assumptions regarding the future in the visualization and formulation to proposed of proposed activation believed necessary to achieve desired result", artinya perencanaan adalah pemilih fakta dan penghubungan faktafakta serta pembuatan dan penggunaan perkiraan-perkiraan atau asumsi-asumsi untuk masa yang akan datang dengan jalan menggambarkan dan merumuskan kegiatan-kegiatan yang diperlukan untuk mencapai hasil yang diinginkan.

Kemudian George R. Terry (dalam Sukarna, 2011:38) juga mengemukakan bahwa "organizing is the determining, grouping and arranging of the various activities needed necessary for the attainment of the objectives, the assigning of the people to these activities, the providing of suitable physical factors of environment and the indicating of the relative authority delegated to each respective activity", yang artinya pengorganisasian adalah penentuan, pengelompokkan, dan penyusunan macammacam kegiatan yang diperlukan untuk mencapai tujuan, penempatan orang-orang (pegawai) terhadap kegiatan-kegiatan ini, penyediaan faktor-faktor fisik yang cocok bagi keperluan kerja dan penunjukkan hubungan wewenang yang dilimpahkan terhadap setiap orang dalam hubungannya dengan pelaksanaan setiap kegiatan yang diharapkan.

Selanjutnya, George R. Terry (dalam Sukarna, 2011:82) mengatakan bahwa "actuating is setting all members of the group to want to achieve and to strike to achieve the objective willingly and keeping with the managerial planning and organizing efforts", artinya penggerakan ialah membangkitkan dan mendorong semua anggota kelompok agar berkehendak dan berusaha dengan keras untuk mencapai tujuan dengan ikhlas serta serasi dengan perencanaan dan usaha-usaha pengorganisasian dari pihak pimpinan.

Fungsi manajaemen yang terakhir menururt Terry adalah pengawasan. Terry berpendapat bahwa "controlling can be defined as the process of determining what is to accomplished, that is the standard, what is being accomplished. That is the performance, evaluating the performance, and if the necessary applying corrective measure so that performance takes place according to plans, that is conformity with 
the standard", artinya adalah pengawasan dapat dirumuskan sebagai proses penentuan apa yang harus dicapai yaitu standar, apa yang sedang dilakukan yaitu pelaksanaan, menilai pelaksanaan, dan jika perlu melakukan perbaikan-perbaikan sehingga pelaksanaan sesuai dengan rencana, yaitu selaras dengan standar.

Fungsi-fungsi manajemen merupakan proses yang ada di dalam aktivitas manajemen untuk meraih tujuan yang diinginkan. Dari pendapat Terry mengenai fungsi-fungsi manajemen, dapat diketahui bahwa dalam melaksanakan perencanaan, pengorganisasian, penggerakan, dan pengawasan harus dilakukan secara sistematis karena keempat fungsi tersebut memiliki keterkaitan.

Dengan demikian dapat ditarik kesimpulan bahwa, perencanaan bertujuan untuk merumuskan fakta mengenai apa yang dimiliki sekarang dan menggunakan asumsi untuk memikirkan cara meraih tujuan yang diinginkan di masa depan. Pengorganisasian adalah penempatan sumber daya manusia yang layak untuk melakukan macam-macam kegiatan sesuai dengan kemampuannya dalam rangka mencapai tujuan dan bertanggung jawab atas wewenang yang telah diberikan. Penggerakan adalah usaha nyata dari sumber daya manusia yang ada dalam menggapai tujuan, sesuai dengan perencanaan yang telah dibuat serta pengorganisasian dari pimpinan. Pengawasan adalah proses mengawasi pelaksanaan kegiatan agar sesuai rencana, serta melakukan evaluasi (perbaikan) terhadap pelaksanaan kegiatan.

\section{Manajemen Pembiayaan Pendidikan}

Menurut Nanang Fattah (dalam Syukri, Sitompul, dan Banurea; 2020:2) pembiayaan pendidikan merupakan jumlah uang yang dihasilkan dan dibelanjakan untuk berbagai keperluan penyelenggaran pendidikan yang mencakup gaji guru, peningkatan profesionalisme guru, pengadaan sarana ruang belajar, perbaikan ruang, pengadaan peralatan, buku pelajaran, alat tulis kantor, pendukung kegiatan ekstra kurikuler, kegiatan pengelolaan pendidikan, dan supervisi pendidikan.

Menurut Levin (dalam Masditou, 2017:125) pembiayaan sekolah adalah proses dimana pendapatan dan sumber daya yang tersedia digunakan untuk memformulasikan dan mengoperasionalkan sekolah di berbagai wilayah geografis dan tingkat pendidikan yang berbeda-beda. Tergantung dari kondisi masing-masing negara seperti kondisi geografis, tingkat pendidikan, kondisi politik pendidikan, hukum pendidikan, ekonomi pendidikan, program 
pembiayaan pemerintah dan administrasi sekolah (Feronika, 2015).

Sementara itu, menurut Rusdiana dan Wardija (2013:2) bahwa manajemen pembiayaan pendidikan adalah rangkaian aktivitas yang mengatur keuangan sekolah mulai dari dari perencanaan, pembukuan, pembelanjaan, pengawasan, dan pertanggungjawaban keuangan sekolah. Hal senada dijelaskan oleh Arwildayanto, Lamatenggo, dan Sumar (2017:2) bahwa manajemen keuangan pendidikan merupakan suatu kegiatan yang dilakukan pimpinan dalam menggerakkan para bawahannya untuk menggunakan fungsifungsi manajemen, meliputi perencanaan keuangan (penganggaran), pengelolaan berupa pengeluaran (pencairan), penggunaan, pencatatan, pemeriksaan, pengendalian, penyimpanan dana, pertanggungjawaban dan pelaporan uang yang dimiliki oleh suatu institusi (organisasi), termasuk di dalamnya lembaga yang menyelenggarakan layanan pendidikan. Intinya dari manajemen keuangan pendidikan, mengelola uang yang ada, menyiapkan dan melaksanakan instrumen adminsitratif untuk mencapai hasil yang efektif dan efisien.

Dari beberapa pendapat di atas, dapat diartikan bahwa pembiayaan sekolah adalah aktivitas memproses pendapatan (input) yang tersedia, kemudian digunakan untuk belanja keperluan operasional pendidikan sesuai kondisi masing-masing sekolah.

Kemudian, manajemen pembiayaan pendidikan adalah aktivitas mengatur keuangan sekolah melalui fungsi-fungsi manajemen mulai dari perencanaan, pembukuan, penggunaan keuangan atau pembelanjaan, pencatatan, pengawasan, serta pertanggungjawaban yang diharapkan akan tercipta tata kelola keuangan sekolah yang efektif dan efisien dalam mencapai tujuan pendidikan.

\section{Mutu Pendidikan}

Armand V. Feigenbaum menyatakan pendapat bahwa mutu adalah kepuasan pelanggan sepenuhnya (full customer satisfaction). Menurut Garvin sebagaimana dikutip oleh M.N. Nasution, kualitas adalah suatu kondisi dinamis yang berhubungan dengan produk, manusia atau tenaga kerja, proses dan tugas, serta lingkungan yang memenuhi atau melebihi harapan pelanggan atau konsumen. Crosby mendefiniskan mutu kualitas adalah conformance to requirement, yaitu sesuai yang diisyaratkan atau distandarkan (dalam Baharun dan Zamroni, 2017:63)

Sedangkan dalam Kamus Besar Bahasa Indonesia (KBBI), pengertian mutu adalah (ukuran) baik buruk suatu benda; kadar; taraf atau derajat (kepandaian, 
kecerdasan, dan sebagainya). Dengan demikian dapat disimpulkan, bahwa mutu adalah ukuran atau taraf suatu produk sesuai yang diisyaratkan atau distandarkan untuk memenuhi kepuasan pelanggan.

\section{Manajemen Pembiayaan Pendidikan untuk Meningkatkan Mutu Pendidikan}

Berdasarkan berbagai pendapat dan uraian tersebut di atas, maka dapat diketahui, bahwa pada konteks mutu pendidikan, mutu mengacu pada input, proses, dan output. Pada buku Manajemen Peningkatan Mutu Berbasis Sekolah yang dikeluarkan oleh Depertemen Pendidikan Nasional, menyebutkan bahwa salah satu input yang penting adalah sumber daya yang tersedia dan siap. Sumber daya sebagai input adalah hal penting yang diperlukan untuk berlangsungnya proses pendidikan di sekolah. Jika sumber daya yang ada tidak siap dan tidak memadai, maka pada gilirannya sasaran sekolah tidak akan tercapai. Sumber daya dikelompokkan menjadi dua, yaitu sumber daya manusia dan sumber daya selebihnya (uang, peralatan, perlengkapan bahan, dan sebagainya).

Proses pada sekolah memiliki sejumlah karakteristik, seperti proses belajar mengajar yang efektivitasnya tinggi, pengelolaan tenaga kependidikan yang efektif, sekolah memiliki budaya mutu, sekolah memiliki transparansi manajemen, sekolah melakukan evaluasi dan perbaikan yang berkelanjutan, dan lainlain.

Sedangkan output sekolah adalah prestasi yang dihasilkan oleh proses pembelajaran dan manajemen di sekolah. Secara umum, output dapat diklasifikasikan menjadi dua, yaitu output berupa prestasi akademik dan output berupa prestasi nonakademik.

Seperti yang telah dipaparkan pada buku Manajemen Peningkatan Mutu Berbasis Sekolah, bahwa salah satu input terpenting adalah biaya. Biaya pendidikan adalah nilai ekonomi dari input atau sumber-sumber pendidikan tertentu yang berdampak pada output yang dihasilkan oleh sekolah berupa lulusan yang bermutu. Pendidikan sebagai unsur utama dalam pengembangan sumber daya manusia yang bermutu tinggi, memiliki peranan penting pada kemajuan bangsa. Lulusan yang bermutu, bergantung pada mutu pendidikan yang diperoleh. Menurut Saifudin (2017) pembiayaan pendidikan merupakan investasi sumber daya manusia jangka panjang.

Pembiayaan pendidikan ini sangat diperlukan untuk program sekolah, pengadaan sarana dan prasarana, gaji guru, gaji pegawai, keperluan untuk menunjang tercapainya visi dan misi sekolah dan 
menciptakan sumber daya manusia yang berkualitas. Kolerasi yang tercipta antara pembiayaan sekolah dengan mutu pendidikan dapat terlihat jelas dalam kegiatan belajar mengajar. Kedua hal tersebut juga tidak lepas dari proses pengelolaan (manajemen). Maka dari itu, proses belajar mengajar di sekolah tidak akan berjalan jika tidak ada manajemen pembiayaan yang efektif dan efisien yang akan membantu mencapai tujuan pendidikan. Dengan manajemen pembiayaan pendidikan yang baik, maka sekolah juga dapat meningkatkan mutu pendidikan.

Dengan melaksanakan fungsifungsi manajemen pembiayaan pendidikan mulai dari perencanaan, pembukuan, penggunaan keuangan atau pembelanjaan, pencatatan, pengawasan, hingga pertanggungjawaban, sekolah dapat terbantu dalam meraih tujuan. Kepala sekolah, komite sekolah, guru, dan karyawan bersama-sama dalam mengelola keuangan sekolah agar mampu meningkatan kualitas pendidikan.

\section{Kesimpulan}

Secara umum, manajemen pembiayaan pendidikan adalah proses mengelola dan mengatur keuangan sekolah secara efektif dan efisien untuk meraih tujuan pendidikan dan meningkatkan mutu pendidikan di sekolah. Manajemen pembiayaan pendidikan memiliki hubungan yang erat dengan mutu pendidikan di sekolah. Sehingga, dengan tata kelola keuangan sekolah yang baik, diharapkan manajemen lainnya juga baik, sehingga dapat menghasilkan lulusan yang bermutu tinggi.

\section{Daftar Pustaka}

Arwildayanto, Lamatenggo, N., \& Sumar, W. N. (2017). Manajemen pembiayaan dan keuangan pendidikan jilid I: Program pendidikan untuk rakyat (prodira) akselerasi pemerataan dan peningkatan jenjang layanan pendidikan di Provinsi Gorontalo. Bandung: P.T Widya Padjajaran.

Baharun, H. \& Zamroni. (2017). Manajemen mutu pendidikan ikhtiar dalam meningkatkan mutu pendidikan madrasah melalui pendekatan balanced scorecard. Tulungagung: Akademia Pustaka.

Danim, S. (2005). Visi baru manajemen sekolah dari unit birokrasi ke lembaga akademik. Jakarta: P.T Bumi Aksara.

Depdiknas. (2001). Manajemen peningkatan mutu berbasis sekolah. Jakarta: Depdiknas.

Depdiknas. (2005). Peraturan Pemerintah Nomor 19 Tahun 2005 tentang Standar Nasional Pendidikan. Jakarta: Depdiknas. 
Depdiknas. (2003). Undang-undang Republik Indonesia Nomor 20 Tahun 2003 tentang Sistem Pendidikan Nasional. Jakarta: Depdiknas.

Fattah, N. (2004). Konsep manajemen berbasis sekolah (MBS) dan dewan sekolah. Bandung: C.V Pustaka Bani Quraisy.

Feronika, R. (2015). Pembiayaan pendidikan di Indonesia. Jurnal Ilmiah Pendidikan Dasar. Vol 2, No1.

http://jurnal.unissula.ac.id/index.ph p/pendas/article/view/755/632

Diakses pada tanggal 16 Desember 2021.

Hasibuan, M. S. P. (2014). Manajemen sumber daya manusia: Edisi revisi. Jakarta: P.T Bumi Aksara.

Lahaji \& Yusuf, H. (2020). Pokoknya manajemen pembiayaan pendidikan. Tulungagung: Cahaya Abadi.

Masditou. (2017). Manajemen pembiayaan pendidikan menuju pendidikan yang bermutu. Jurnal ANSIRU PAI. Vol 1, No 2. http://dx.doi.org/10.30821/ansiru.v 1i2.1518.g1245 Diakses pada tanggal 14 Desember 2021.

Rusdiana \& Wardija. (2013). Manajemen keuangan sekolah (konsep, prinsip, dan aplikasinya di sekolah/madrasah). Bandung: Arsad Press.
Saifudin, A. (2017). Analisis manajemen pembiayaan pendidikan dalam meningkatkan kualitas sumber daya manusia menurut perspektif ekonomi Islam. Skripsi. http://repository.radenintan.ac.id/id leprint/1869 Diakses pada tanggal 19 Desember 2021.

Sukarna. (2011). Dasar-dasar manajemen. Bandung: C.V Mandar Maju.

Syukri, M., Sitompul, I., \& Banurea, O. K. (2020). Manajemen pembiayaan pendidikan. Medan: C.V Pusdikra Mitra Jaya.

Kamus Besar Bahasa Indonesia kamus versi online/daring (dalam jaringan).https://kbbi.web.id/ Diakses pada tanggal 18 Desesmber 2021. 